\title{
EVALUATION OF THREE SCENARIOS OF GROUND-WATER WITHDRAWAL FROM THE MISSISSIPPI RIVER ALLUVIAL AQUIFER IN NORTHWESTERN MISSISSIPPI
}

By Michael J. Mallory

U.S. GEOLOGICAL SURVEY

Open-File Report 90-103

Prepared in cooperation with the

U.S. ARMY CORPS OF ENGINEERS, VICKSBURG DISTRICT

Jackson, Mississippi

1990 


\section{CONVERSION FACTORS}

For readers who may prefer to use the metric (International System) of units rather than the inch-pound units used herein, the conversion factors are listed below:

Multiply inch-pound unit

inch (in.)

foot $(\mathrm{ft})$

mile (mi)

square mile $\left(\mathrm{mi}^{2}\right)$

million gallons per day (Mgal/d)

foot squared per day $\left(\mathrm{ft}^{2} / \mathrm{d}\right)$
By

25.4

0.3048

1.609

2.590

0.04381

0.0920

\section{To obtain metric unit}

millimeter (mm)

meter $(m)$

kilometer (km)

square kilometer $\left(\mathrm{km}^{2}\right)$

cubic meter per second $\left(\mathrm{m}^{3} / \mathrm{s}\right)$

meter (squared per day $\left(\mathrm{m}^{2} / \mathrm{d}\right)$

Temperature in degrees Fahrenheit $\left({ }^{\circ} \mathrm{C}\right)$ as follows:

$$
{ }^{\circ} \mathrm{F}=1.8 \times{ }^{\circ} \mathrm{C}+32
$$

Sea Level: In this report, "sea level" refers to the National Geodetic Vertical Datum of 1929 (NGVD of 1929)--a datum derived from a general adjustment of the first-order level nets of both the United States and Canada, formerly called Sea Level Datum of 1929. 


\section{DEPARTMENT OF THE INTERIOR \\ MANUEL LUJAN, JR., Secretary \\ U.S. GEOLOGICAL SURVEY \\ Dallas L. Peck, Director}

For additional information write to:

District Chief

U.S. Geological Survey

$100 \mathrm{~W}$. Capitol Street

Suite 710, Federal Building

Jackson, Mississippi 39269
Copies of this report can be purchased from:

U.S. Geological Survey

Books and Open-File Reports

Building 810

Federal Center, Box 25425

Denver, Colorado 80225 


\section{CONTENTS}

Page

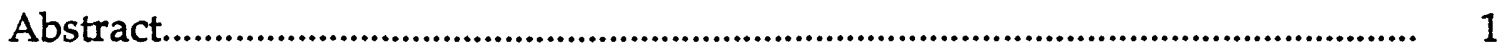

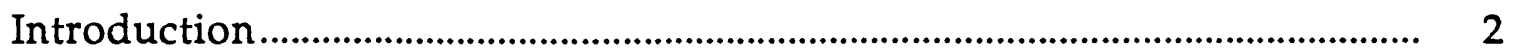

Purpose and scope

Description of the study area................................................................. 2

Effects of ground-water pumping............................................................................ 3

Description of the ground-water model ........................................................ 3

Results of modeled scenarios........................................................................ 3

Baseline scenario................................................................................ 3

Proposed project scenario.............................................................................. 4

Proposed project combined with conservation measures scenario....... 5

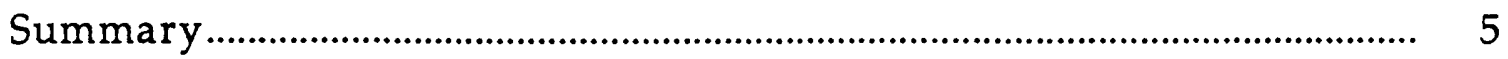

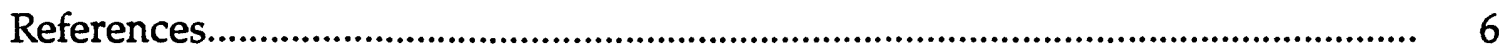




\section{ILLUSTRATIONS}

Page

Figure 1. Map showing culture of the Delta and overlay of digital model grid

2. Graph showing pumpages assumed for the three scenarios for the period 1990 through 2030

3. Map showing simulated potentiometric surface of the Mississippi River alluvial aquifer for scenario 1 at year 2030 .

4. Map showing simulated drawdown from 1985 levels of the Mississippi River alluvial aquifer for scenario 1 at year 2030 .

5. Map showing simulated saturated thickness of the Mississippi River alluvial aquifer for scenario 1 at year 2030 .

6. Map showing simulated potentiometric surface of the Mississippi River alluvial aquifer for scenario 2 at year 2030

7. Map showing simulated drawdown from 1985 of the Mississippi River alluvial aquifer for scenario 2 at year 2030 ....

8. Map showing simulated saturated thickness of the Mississippi River alluvial aquifer for scenario 2 at year 2030 .

9. Map showing simulated potentiometric surface of the Mississippi River alluvial aquifer for scenario 3 at year 2030

10. Map showing simulated drawdown from 1985 levels of the Mississippi River alluvial aquifer for scenario 3 at year 2030 .

11. Map showing simulated saturated thickness of the Mississippi River alluvial aquifer for scenario 3 at year 2030 


\title{
EVALUATION OF THREE SCENARIOS OF GROUND-WATER WITHDRAWAL FROM THE MISSISSIPPI RIVER ALLUVIAL AQUIFER IN NORTHWESTERN MISSISSIPPI
}

\author{
By Michael J. Mallory
}

\begin{abstract}
The U.S. Army Corps of Engineers, Vicksburg District, is investigating the feasibility of a project to supply surface water to agricultural water users to reduce the pumping stress on the Mississippi River alluvial aquifer in northwestern Mississippi. This report evaluates three scenarios of ground-water withdrawal from the aquifer using an existing ground-water flow model. The three scenarios represent, respectively: 1) a projection of current trends of ground-water pumpage, 2) ground-water pumpage that could be expected with the proposed surface-water diversion project supplying surface water to many of the current ground-water users, and, 3) groundwater pumpage that could be expected with the surface-water diversion project in operation and with the remaining groundwater users following best available technology water conservation practices.

Results for the first scenario, reflecting continuation of current trends, indicate that the aquifer would be completely dewatered in some locations as early as 2007 and that, by 2030 , the aquifer underlying an area of more than 800,000 acres of the Delta

(northwestern Mississippi) would be completely dewatered.

Results for the second scenario, which reflects the effects of the proposed surfacewater diversion project, show a dramatic decrease in the rate of decline of groundwater levels as compared to the first scenario. In 2030, under the second scenario, about three-fourths of the Delta would have a saturated aquifer thickness of greater than 100 feet. Water-level declines from 1985 levels would be greatest in southern Sunflower and northeastern Washington Counties and generally would be less than 50 feet in these areas.

Results of the third scenario, reflecting the effects of the surface-water diversion project combined with groundwater conservation measures, resulted in a substantial incremental decrease in the rate of decline of water levels. Maximum declines from 1985 levels under this scenario generally are less than 30 feet, an increase of about 20 feet from the second scenario. Saturated thickness is increased by a similar amount.
\end{abstract}




\section{INTRODUCTION}

The Yazoo River basin in northwestern Mississippi is located in the Mississippi River alluvial plain locally known as the "Delta." The basin is underlain by a prolific aquifer referred to locally as the Mississippi River alluvial aquifer. This aquifer is a discontinuous part of a larger aquifer which extends into Arkansas and Louisiana and is referred to throughout its regional extent as the Mississippi River valley alluvial aquifer in recent reports of the U.S. Geological Survey. In 1985, the aquifer supplied about 1,100 Mgal/d (million gallons per day) of water. This large ground-water withdrawal has caused extensive declines in ground-water levels and substantially exceeds the rate of replenishment to the aquifer. To aid in the understanding and management of the ground-water resources in the Delta, a hydrologic study, including the development of a digital ground-water flow model, was made by the U.S. Geological Survey (Sumner and Wasson, 1984). The U.S. Army Corps of Engineers is currently investigating various plans to supply surface water as a supplemental or alternative source for the ground water currently used for irrigation in the Yazoo River basin.

\section{Purpose and Scope}

The purpose of this investigation was to use the ground-water flow model developed by Sumner and Wasson (1984) to simulate effects of ground-water withdrawals consistent with scenarios of conjunctive ground- and surface-water withdrawals and the use of alternative supplies proposed by the Corps.

This report presents the results of the investigation evaluating the effects of three pumpage scenarios developed by the Corps to represent:

- A revised projection of pumpage based on current use patterns in the basin to serve as a baseline for comparison of results with the following projections reflecting effects of the proposed Corps project.

- A scenario in which ground-water withdrawals for irrigation are replaced with surface water provided by the proposed project. In general, under this scenario, all irrigation pumpage for row crops and rice would be replaced with surface water. However, water for aquaculture (mainly catfish farming) would continue to be supplied by ground water because of the stringent water-quality requirements for this industry. Also, under this scenario, water for industrial, livestock, fish and wildlife, and thermoelectric power generation uses--which are currently supplied by ground-water sources-are assumed to continue to be supplied by ground-water pumpage.

- A scenario that, like scenario 2, assumes all irrigation pumpage is replaced by surface-water sources but also assumes that ground-water conservation is practiced by aquacultural users.

More complete details of each of these scenarios are presented in a later section of this report.

\section{Description of the Study Area}

The 7,000-square-mile study area for this investigation (fig. 1) corresponds to that part of the alluvial plain in Mississippi, bounded on the west by the Mississippi River and on the east by the Bluff Hills, an escarpment which rises 100 to 200 feet above the surface of the alluvial plain. The Mississippi River alluvial plain in Mississippi slopes about one-half foot per mile, from an elevation of about 220 feet above sea level near the northern border of the State to an elevation of about 80 feet above sea level near Vicksburg, a distance of about 200 miles. The Yazoo-TallahatchieColdwater River system drains the eastern part of the plain and collects water from many streams that enter the plain from the Bluff Hills to the east. 
The climate of the Delta is temperate. Average annual temperature ranges from $62^{\circ} \mathrm{F}$ near Memphis, Tenn., to $66^{\circ} \mathrm{F}$ near Vicksburg. The normal frost-free growing season extends from early April to early November. Precipitation averages 52 inches annually (Sumner and Wasson, 1984) and is well distributed throughout the year with about 60 percent occurring in the winter and spring and about 40 percent occurring in summer and fall.

The geology of the Delta is described in detail by Summer and Wasson (1984) and will be discussed only briefly in this report. The Mississippi River alluvium, of Quaternary age, was deposited on an erosional surface by the Mississippi River and its tributaries. The coarsest sediments (gravel and very coarse sand) generally occur at or near the base of the formation and tend to be thickest where the alluvium is thickest. The alluvium grades upward to medium or fine sand or clay. The upper part of the alluvium generally consists of clay of variable thickness, but averaging about 20 feet thick. In some abandoned stream channels, clay thickness may be as much as 80 feet. Average thickness of the alluvium is about 140 feet but ranges from about 80 to 240 feet. The alluvial deposits are underlain unconformably by sands, silts, and clays of Tertiary age which dip to the south and southwest.

The alluvial aquifer consists of the coarser alluvium materials. The coarse sands and gravels that comprise the most productive parts of the alluvial aquifer tend to be thickest in the center of the alluvial plain and thinner toward the eastern edge of the Delta. Along the eastern edge of the Delta, where the alluvium abuts the Bluff Hills, the clay cap is lacking and recharge to the aquifer occurs through permeable alluvial fans. Heads in the underlying aquifers in Tertiary sediments along the eastern boundary are higher than heads in the alluvial aquifer, resulting in upward leakage from the aquifers in Tertiary sediments into the alluvial aquifer. At the western edge of the Delta, the Mississippi River is deeply incised into the coarsest parts of the alluvial aquifer and is in virtually complete hydraulic connection with the aquifer. The Mississippi River acts as both a source of recharge and as a drain for the aquifer, depending on season and stage in the river. The net effect of the river, however, is one of recharge to the aquifer. In the interior of the Delta, the Yazoo and Tallahatchie Rivers and, to a lesser extent, the Coldwater and Sunflower Rivers and the Bogue Phalia are in hydraulic connection with the aquifer to varying degrees.

Water levels in the Delta indicate a pattern of regional ground-water flow that generally is from north to south and from the eastern and western edges of the area towards the center. In the central part of the Delta, hydrographs indicate water-level declines in excess of 2 feet per year since 1980 because of increased pumping from the aquifer.

\section{EFFECTS OF GROUND-WATER PUMPING}

\section{Description of the Ground-Water Model}

Sumner and Wasson (1984) developed a computer model of the Delta to simulate the effects of ground-water pumping on the alluvial aquifer. The digital model used was the modular three-dimensional finitedifference ground-water flow model of McDonald and Harbaugh (1984). Calibration of the alluvial aquifer model resulted in the following estimates of hydraulic parameters of the alluvial aquifer: transmissivity, $400 \mathrm{ft}^{2} / \mathrm{d}$; specific yield, 0.30; storage coefficient, 0.001 ; areal recharge, $0.5 \mathrm{in} / \mathrm{yr}$; riverbed conductance, 3,000 to $10,000 \mathrm{ft}^{2} / \mathrm{d}$. The finite-difference grid and boundaries of the digital model are shown in figure 1.

\section{Results of Modeled Scenarios}

\section{Baseline Scenario}

To provide a baseline for comparison, a model run was made using pumpage rates representing the best current estimate of 
future pumpage in the Delta based on continuation of current agricultural and aquacultural practice. These projected pumpages were developed by the Vicksburg District, U.S. Army Corps of Engineers, Planning Division, Eastern Tributaries Branch in conjunction with the Department of Agricultural Economics, Mississippi Agricultural and Forestry Experiment Station, Mississippi State University (Laughlin and Reinshmiedt, 1984). Agricultural water use represents about 78 percent of the total water demand in these projections. The water demand projections were tabulated for the years 1990, 2000, 2010, 2020, and 2030 (fig. 2). For purposes of model input data, ground-water demand was distributed areally based on land use and predicted economic and population growth. Average rainfall (52 inches annually) was assumed for the period of the projections. Model runs simulated the aquifer response for the period 1985-2035. The simulated time period was divided into five pumping periods, each of 10 years duration. Pumpage was assumed to remain constant within the pumping periods and to increase in a step-wise fashion from one pumping period to the next. For example, the pumpage tabulated for the year 1990 was applied uniformly to the pumping period that represented the time span 1985 to 1995 based on the assumption that the mid-point value represented a sufficiently accurate average for that period. To better represent the aquifer response through time and to provide information for specific planning horizons, each of the 10-year pumping periods was divided into four equal length time steps, each of $2 \frac{1}{2}$ year's duration. Output was produced at the end of the second time period of each pumping period. Therefore, head and drawdown response of the aquifer predicted in the simulations were analyzed for the years 1990, 2000, 2010, 2020, and 2030. Under this scenario, ground-water pumpage would increase from about 2,200 Mgal/d in 1990 to about 4,000 Mgal/d in 2030 (fig. 2).

Head, water-level decline from 1985 levels, and saturated thickness of the aquifer for the baseline condition at the year
2030 are shown in figures 3,4 , and 5 . These figures show dramatically the inability of the aquifer to support the levels of pumpage projected in this water-demand projection. Results of this simulation indicate that the saturated thickness in the aquifer would decline to zero (that is, the aquifer would begin to go dry) in some areas as early as the first time step of the third pumping period, representing the year 2007; by 2030, the aquifer would be completely dewatered in an area of about 832,000 acres (fig. 5).

\section{Proposed Project Scenario}

The Corps of Engineers, Vicksburg District, is investigating the feasibility of a project to provide surface water for agricultural water users to reduce the pumping stress on the Mississippi River alluvial aquifer system. Elements of this plan, as specified by the Corps, tentatively would include:

(1) Pumping stations to divert water from the Mississippi River into the Sunflower River and Steele Bayou basins.

(2) Diversion channels for transporting water from the Coldwater and Tallahatchie Rivers into the Sunflower and Quiver Rivers, respectively.

(3) Twenty-five in-stream weirs at various locations on Old Coldwater River, Bogue Phalia, Sunflower River, and Quiver River.

(4) Stoplog drainage structures at the confluence of tributaries with major streams.

(5) Greenbelts on either side of major streams to decrease siltation and improve water quality.

(6) Diversion control structures to improve water quality at selected Yazoo basin lakes.

It was assumed that the supplemental surface water made available by the proposed project would be used primarily to meet crop irrigation demands. Water demands for aquaculture were assumed to 
continue to be supplied by ground water because of water-quality considerations. Under this scenario, ground-water pumpage would range from $495 \mathrm{Mgal} / \mathrm{d}$ in 1990 to $1,262 \mathrm{Mgal} / \mathrm{d}$ in 2030 (fig. 2). Figures 6, 7, and 8 show the heads, water-level declines from 1985 levels, and saturated thickness of the aquifer representing supplemental water use and reduced pumpage at the year 2030.

Under the conditions assumed in this scenario, a maximum of about 50 feet of water-level decline from 1985 levels would occur in southern Sunflower and northeastern Washington Counties by 2030 (fig. 7). Saturated thickness in the aquifer would be greater than 100 feet in about three-fourths of the Delta at the end of this simulation (fig. 8). Saturated thickness in the aquifer generally would range from 40 to 100 feet in 2030 in Washington, Sunflower, and Leflore Counties. One node in southern Sunflower County was dewatered during the last decade of this simulation. This seems to have been caused by an unusually high elevation of the base of the aquifer underlying that node.

\section{Proposed Project Combined With Conservation Measures Scenario}

This alternative assumes the same system of surface-water diversions for meeting crop-irrigation demands as the previous scenario. It also assumes the implementation of conservation measures to reduce ground-water consumption by aquacultural water users. With crop irrigation supplied by surface-water sources, aquaculture becomes the largest use of ground water. Under this scenario, ground-water pumpage would increase from about $390 \mathrm{Mgal} / \mathrm{d}$ in 1990 to about $970 \mathrm{Mgal} / \mathrm{d}$ in 2030 (fig. 2).

Figures 9, 10, and 11 show the head, water-level decline from 1985 conditions, and saturated thickness of the aquifer at the year 2030, respectively, under the conditions of this scenario.

Water-level declines of 30 feet below 1985 levels would occur in southern Sunflower and northeastern Washington
Counties by 2030 (fig. 10). Throughout Washington, Sunflower, and Leflore Counties, saturated thickness in the aquifer would be about 10 to 20 feet greater under this scenario than without conservation.

\section{SUMMARY}

Simulations using the digital groundwater flow model developed by Sumner and Wasson (1984) indicate that the Mississippi River alluvial aquifer in northwestern Mississippi (the "Delta") will not be able to meet the increased ground-water demand projected during the next 40 years. Results from a simulation of the ground-water flow system for this period, using ground-water demand projections developed by the Corps of Engineers and Mississippi State University, indicated that the aquifer would begin to go dry as early as 2007 and by 2030 the aquifer underlying about 832,000 acres of the Delta would be completely dewatered.

To alleviate the estimated deficit in available ground water, the Corps of Engineers has proposed to divert surface water from the Mississippi River to supplement ground-water supplies. Two proposals of this project were evaluated using the ground-water flow model. The first of these consists of structural measures to supply surface water to replace virtually all ground water now used for crop irrigation. This simulation resulted in a dramatic increase in projected ground-water levels. The simulation results indicate that in 2030, the saturated thickness of the aquifer would be in excess of 100 feet in about three-fourths of the Delta. Declines in water levels from 1985 levels would be greatest in southern Sunflower and northeastern Washington Counties, where declines of about 50 feet are projected. In general, the saturated thickness of the aquifer in these areas would range from 40 to 100 feet.

The second formulation of the project included both structural and conservation measures. In the design of the project, it was noted that the supplemental surface-water supply probably would not be suited for aquacultural uses, mainly catfish farming, 
because of the unique water-quality requirements for this industry. Recent research, however, has indicated that conservation practices in the aquaculture industry can be effective. The simulation for this scenario assumed a decrease in the amounts of water used by aquaculture, which seems practical with current technology. This simulation showed a significant incremental increase in ground-water levels. Maximum declines under this scenario are about 30 feet below 1985 levels, an improvement of 10 to 20 feet over the simulation of the project conditions without conservation measures. Saturated thickness in the aquifer would be increased by a similar amount.

\section{REFERENCES}

Laughlin, D.H., and Reinshmiedt, L.L., 1984, Agriculture and fish and wildlife water demand study, Yazoo River basin, Vol. I and II: Department of Agricultural Economics, Mississippi Agricultural and Forestry Experiment Station, Mississippi State University, $299 \mathrm{p}$.

McDonald, M.G., and Harbaugh, A.W., 1984, A modular three-dimensional finitedifference ground-water flow model: U.S. Geological Survey Open-File Report 83-875, 528 p.

Sumner, D.M., and Wasson, B.E., 1984, Geohydrology and simulated effects of large ground-water withdrawals on the Mississippi River alluvial aquifer in northwestern Mississippi: U.S. Geological Survey Open-File Report 84-822, 83 p. 


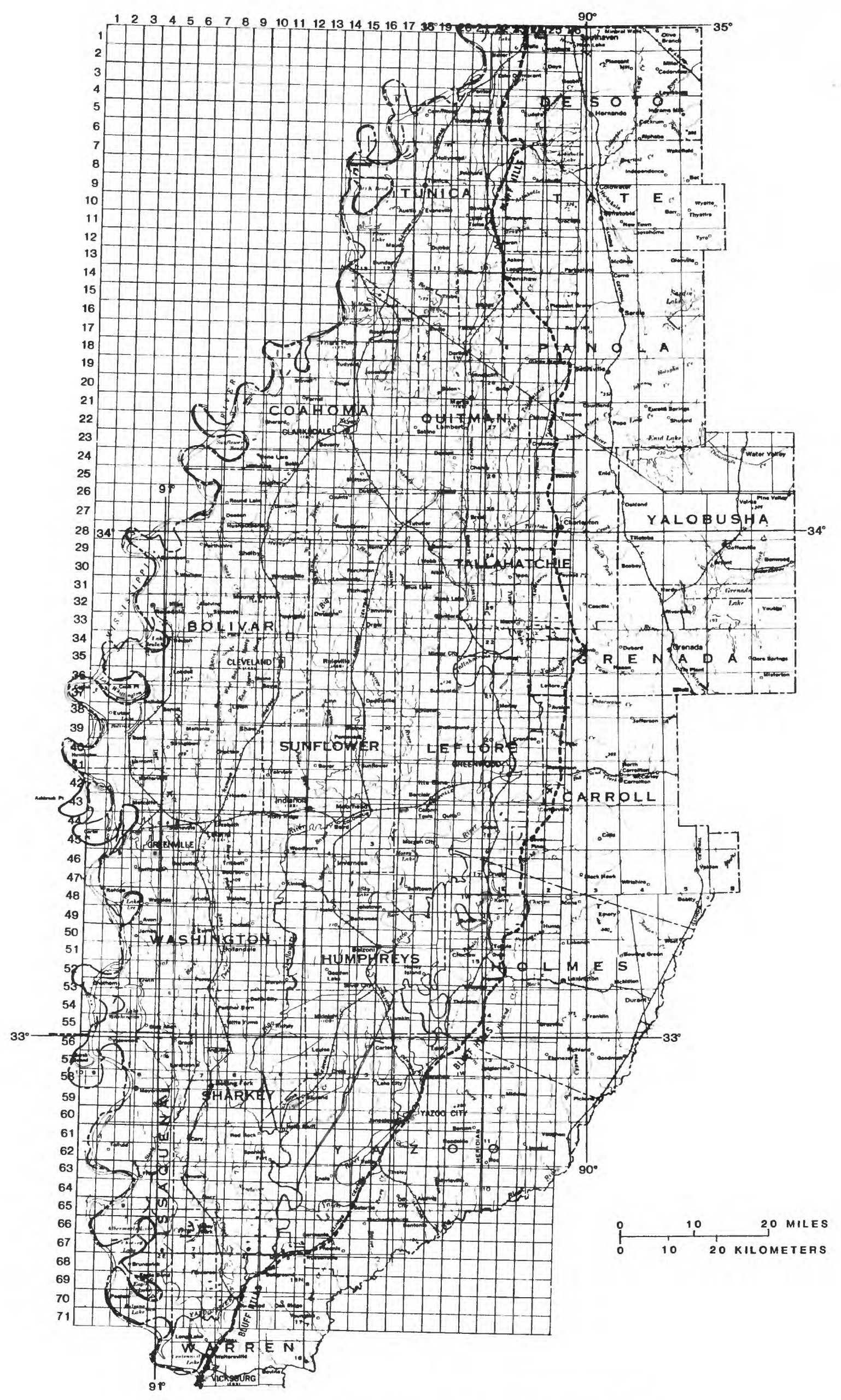

Figure 1.--Culture of the Delta and overlay of digital model grid. 


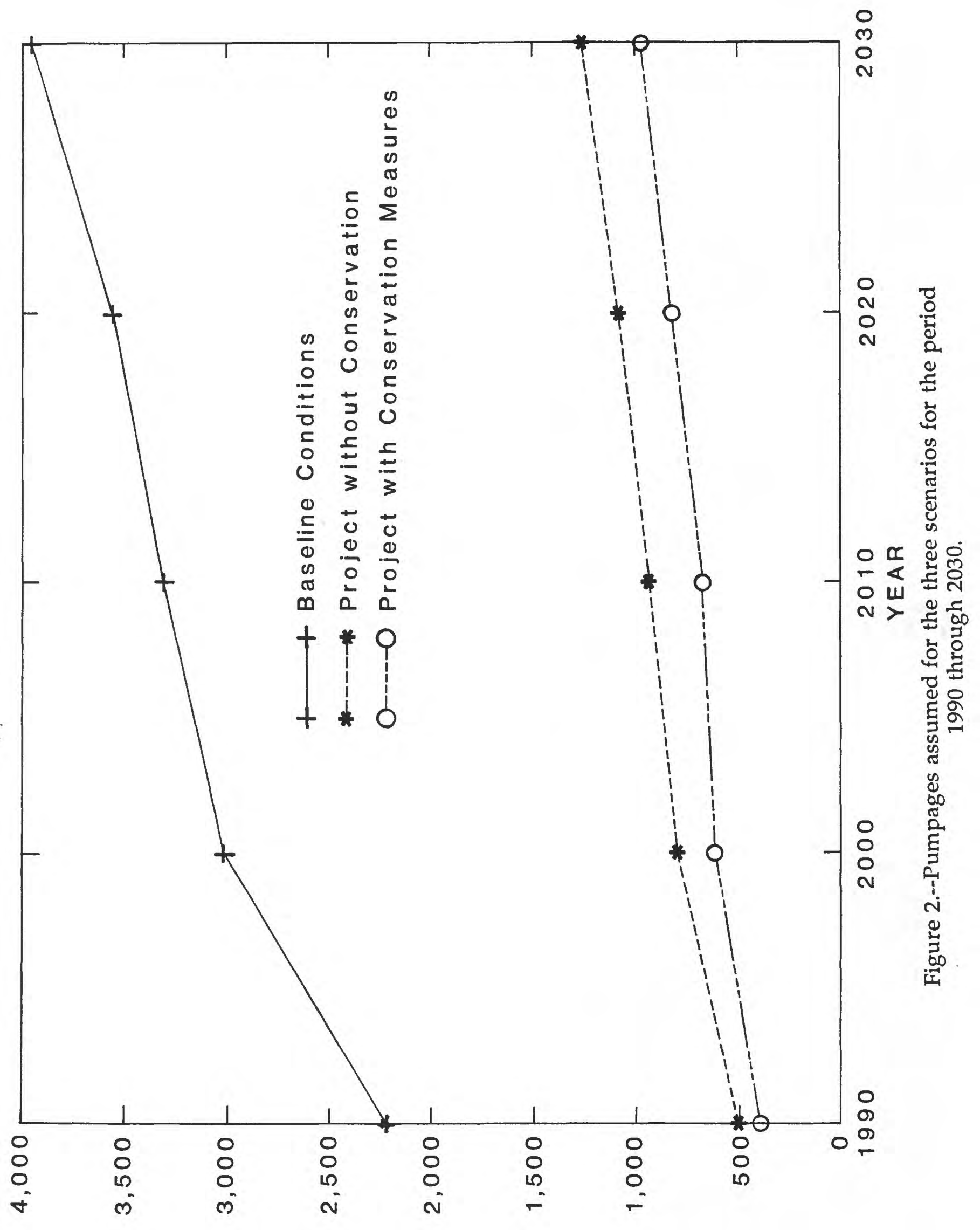

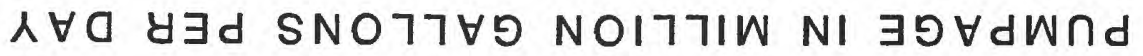




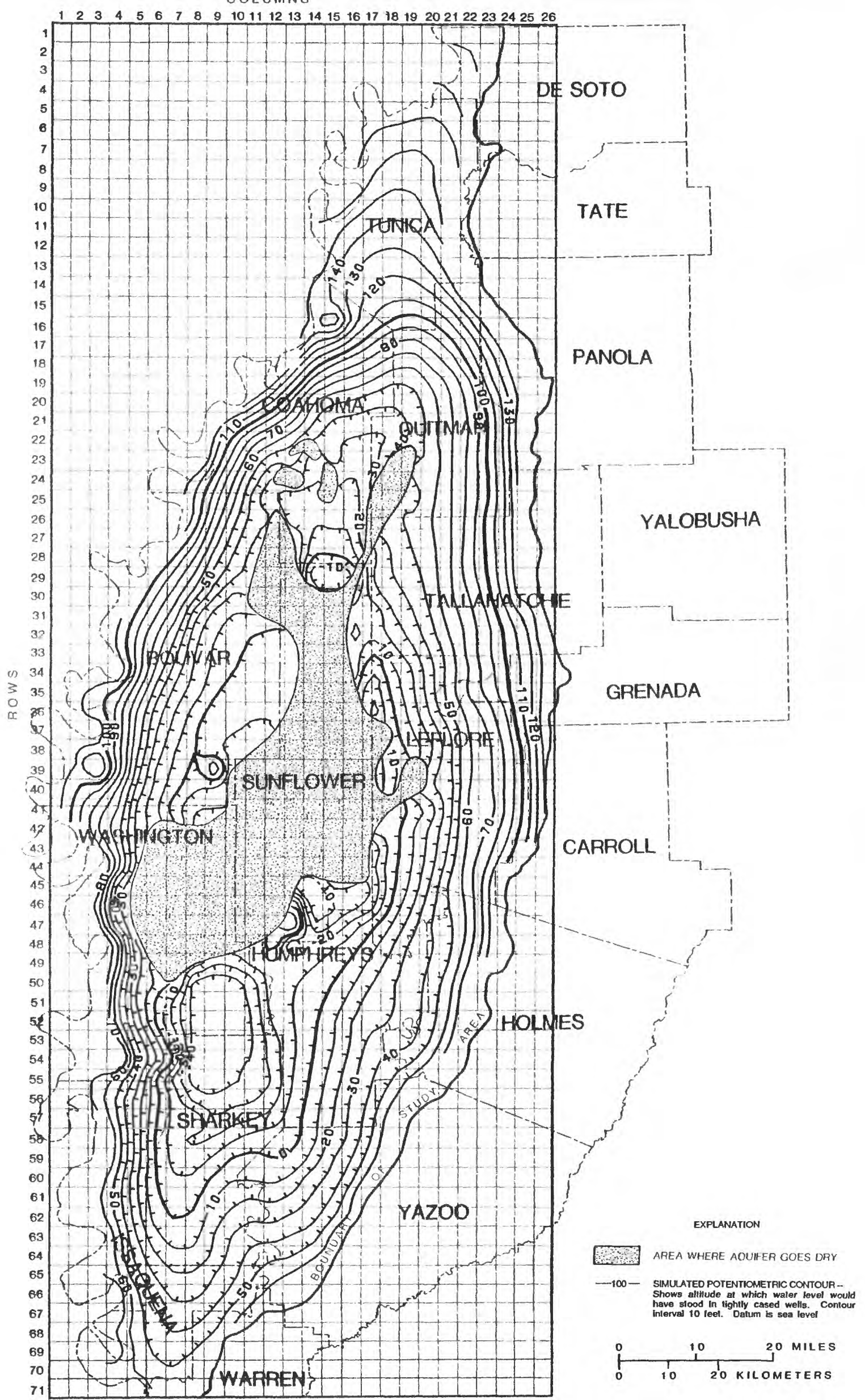

Figure 3.--Simulated potentiometric surface of the Mississippi River alluvial aquifer for scenario 1 at year 2030 . 


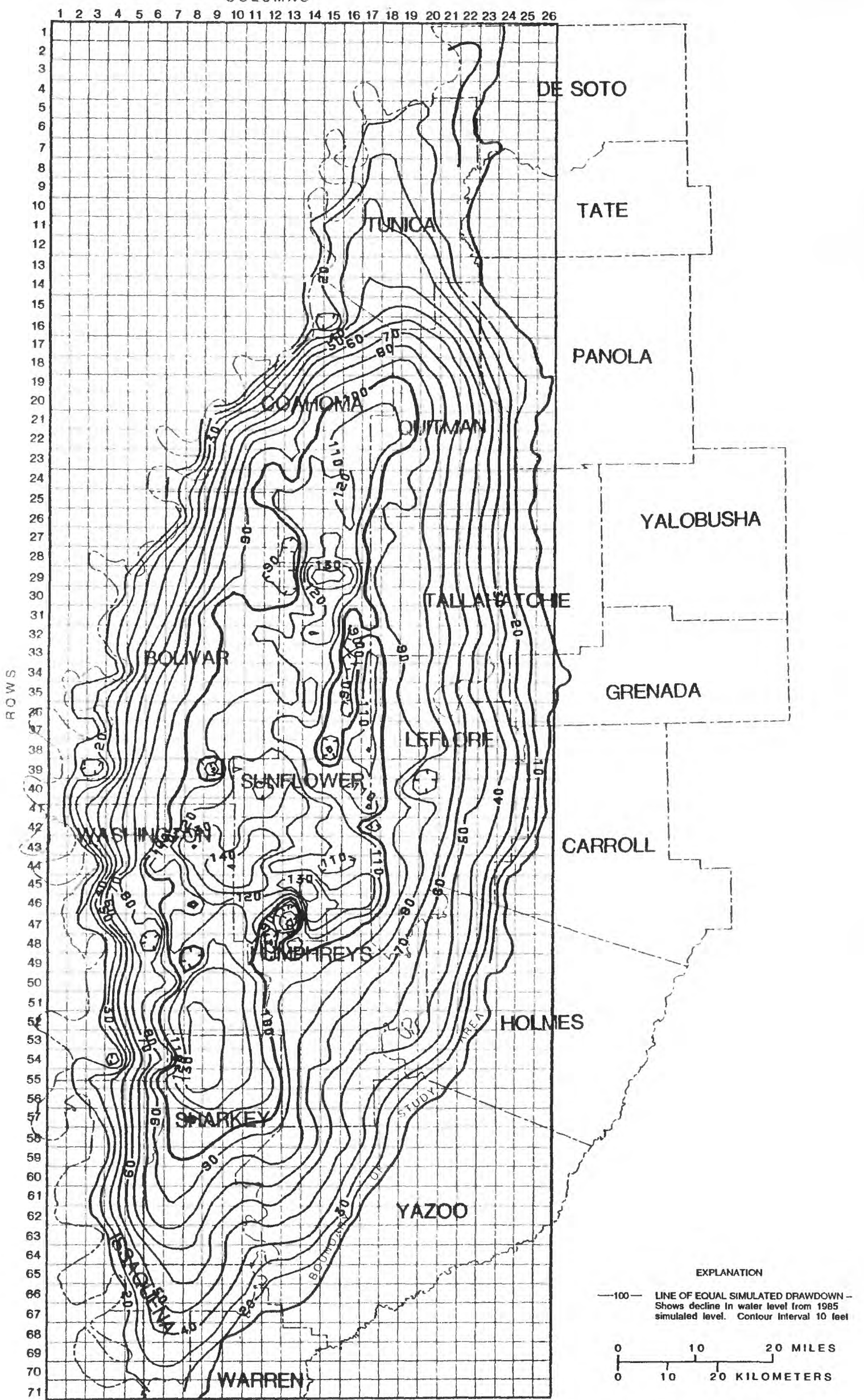

Figure 4.--Simulated drawdown from 1985 levels of the Mississippi River alluvial aquifer for scenario 1 at year 2030 . 


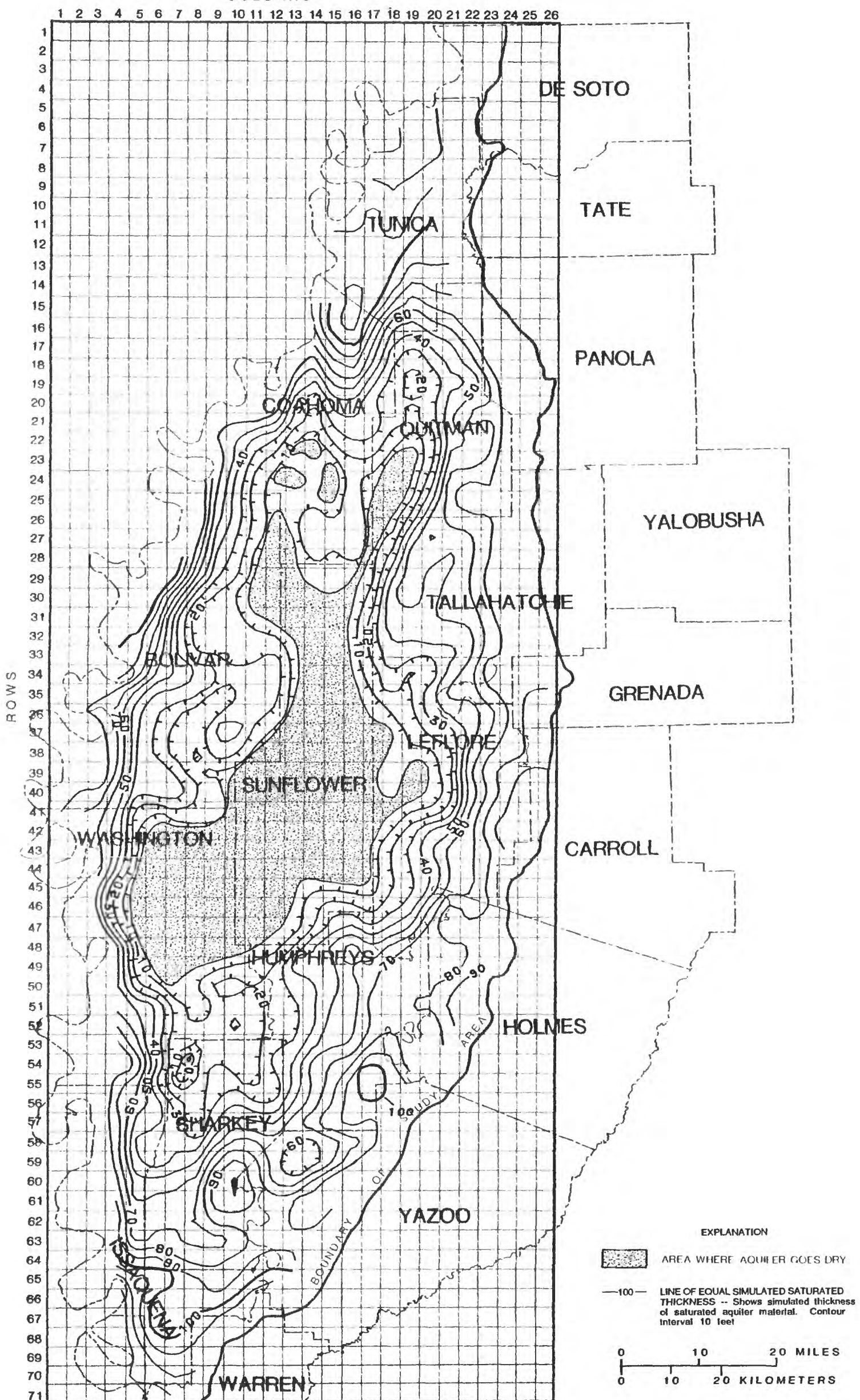

Figure 5.--Simulated saturated thickness of the Mississippi River alluvial aquifer for scenario 1 at year 2030. 


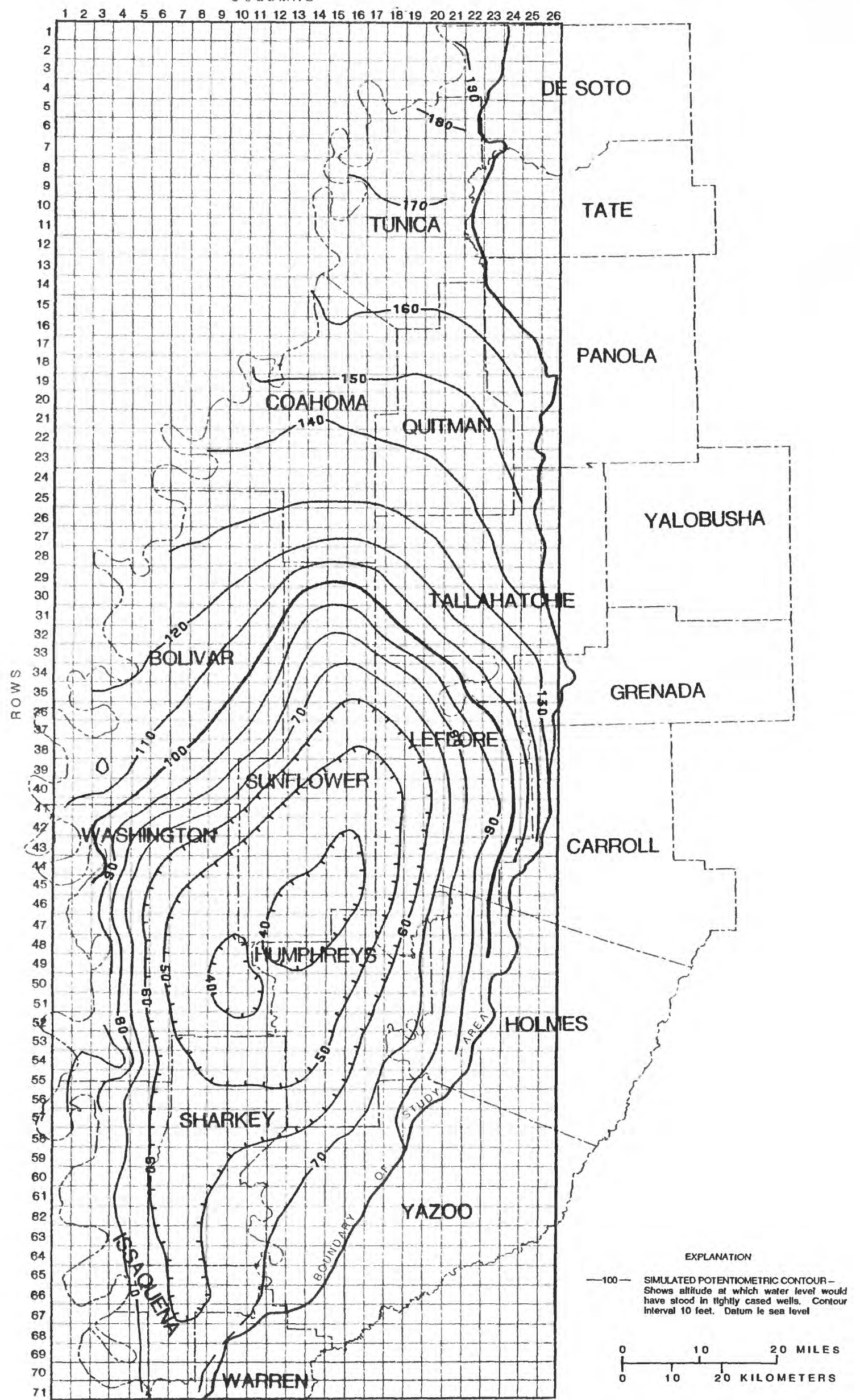

Figure 6.--Simulated potentiometric surface of the Mississippi River alluvial aquifer for scenario 2 at year 2030 


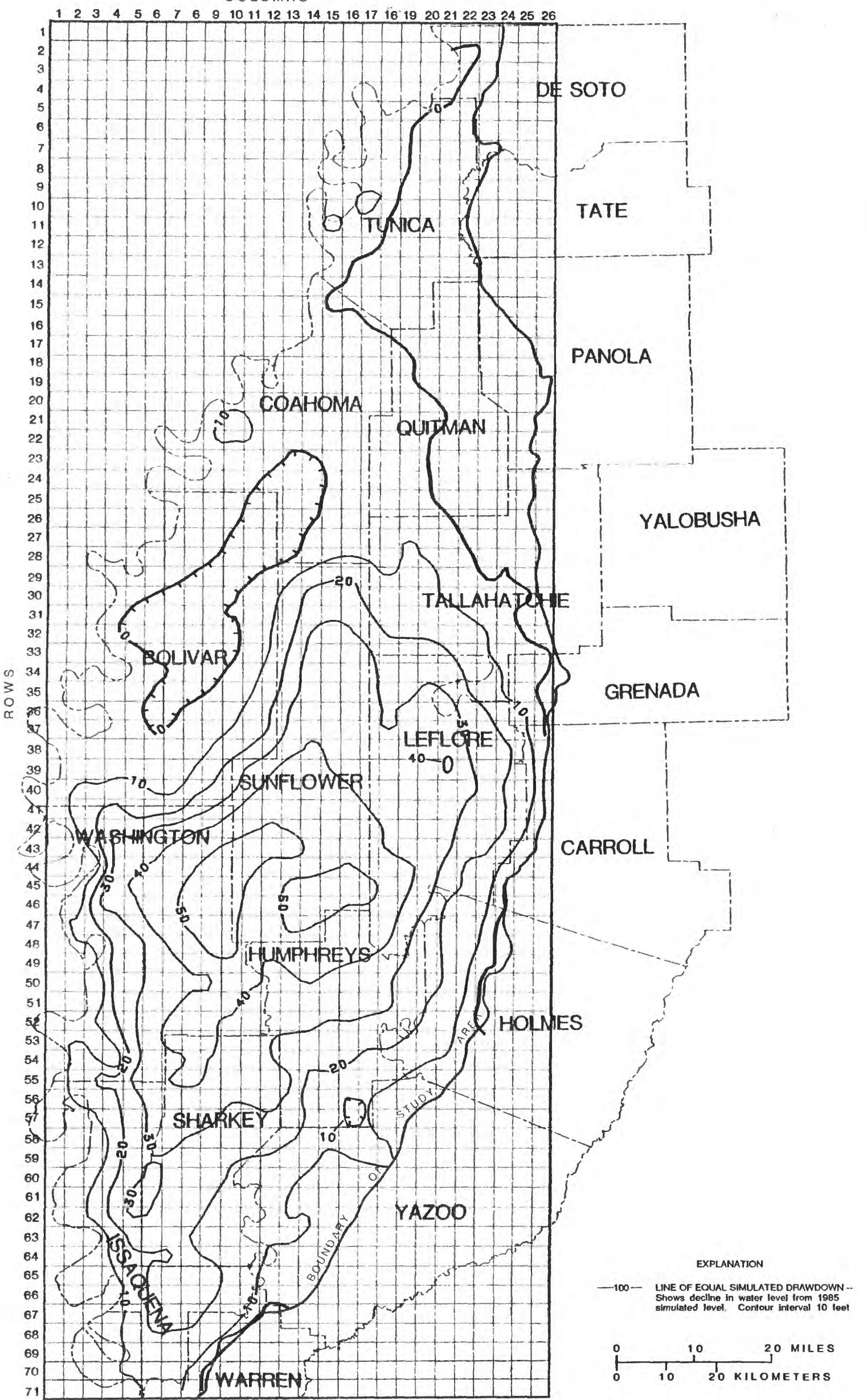

Figure 7.--Simulated drawdown from 1985 of the Mississippi River alluvial aquifer for scenario 2 at year 2030 . 


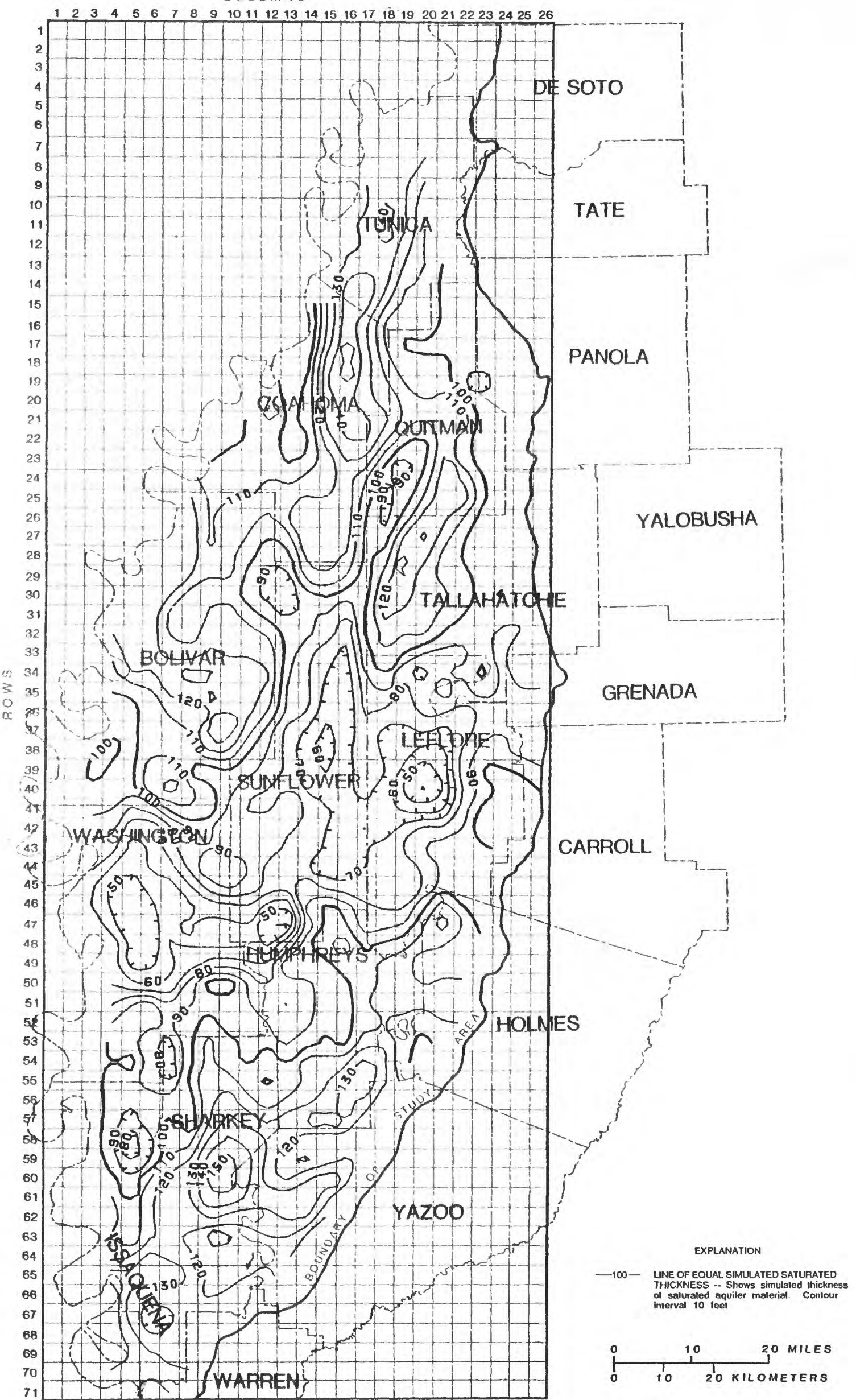

Figure 8.--Simulated saturated thickness of the Mississippi River alluvial aquifer for scenario 2 at year 2030 . 


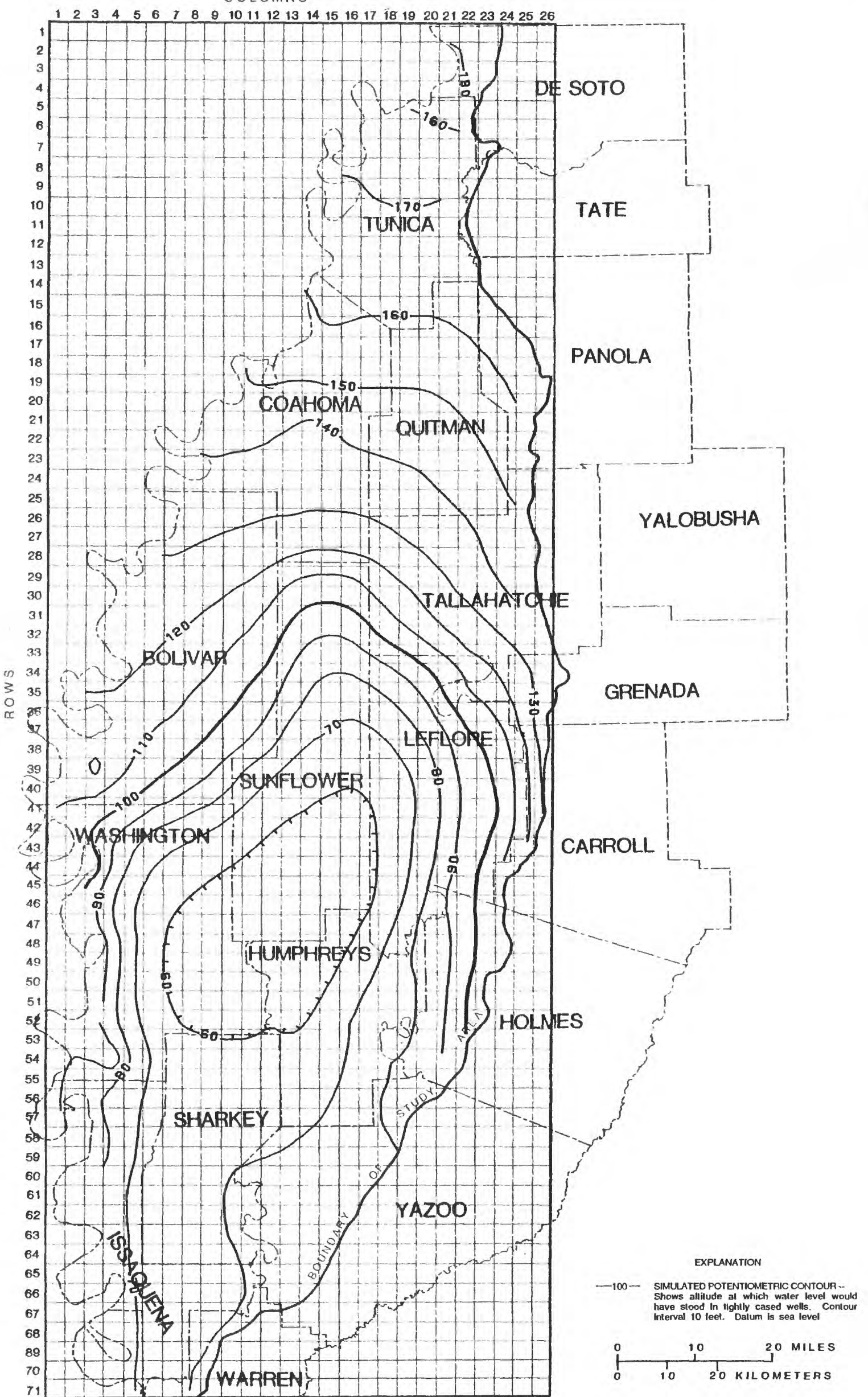

Figure 9.--Simulated potentiometric surface of the Mississippi River alluvial aquifer for scenario 3 at year 2030. 


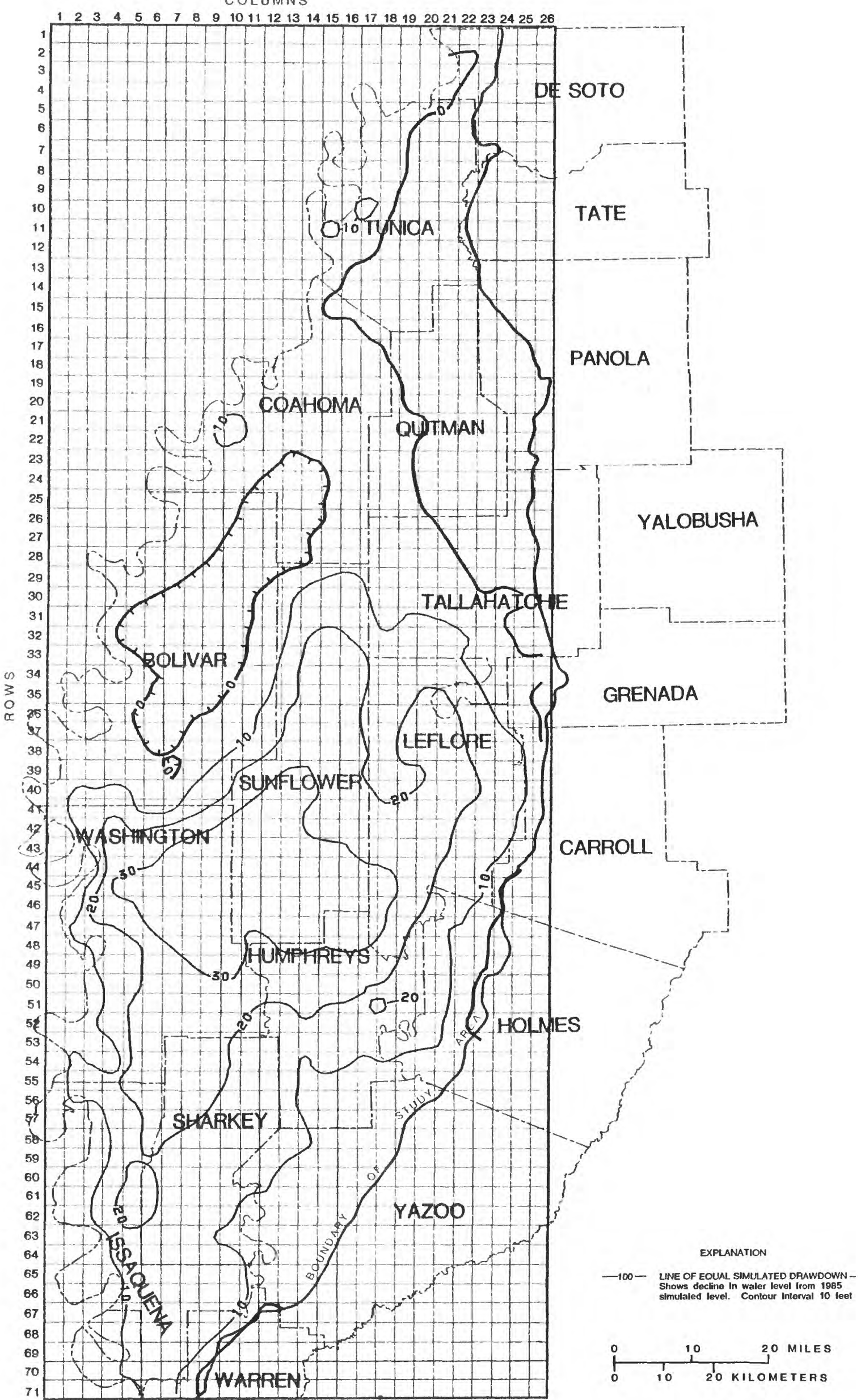

Figure 10.--Simulated drawdown from 1985 levels of the Mississippi River alluvial aquifer for scenario 3 at year 2030 . 


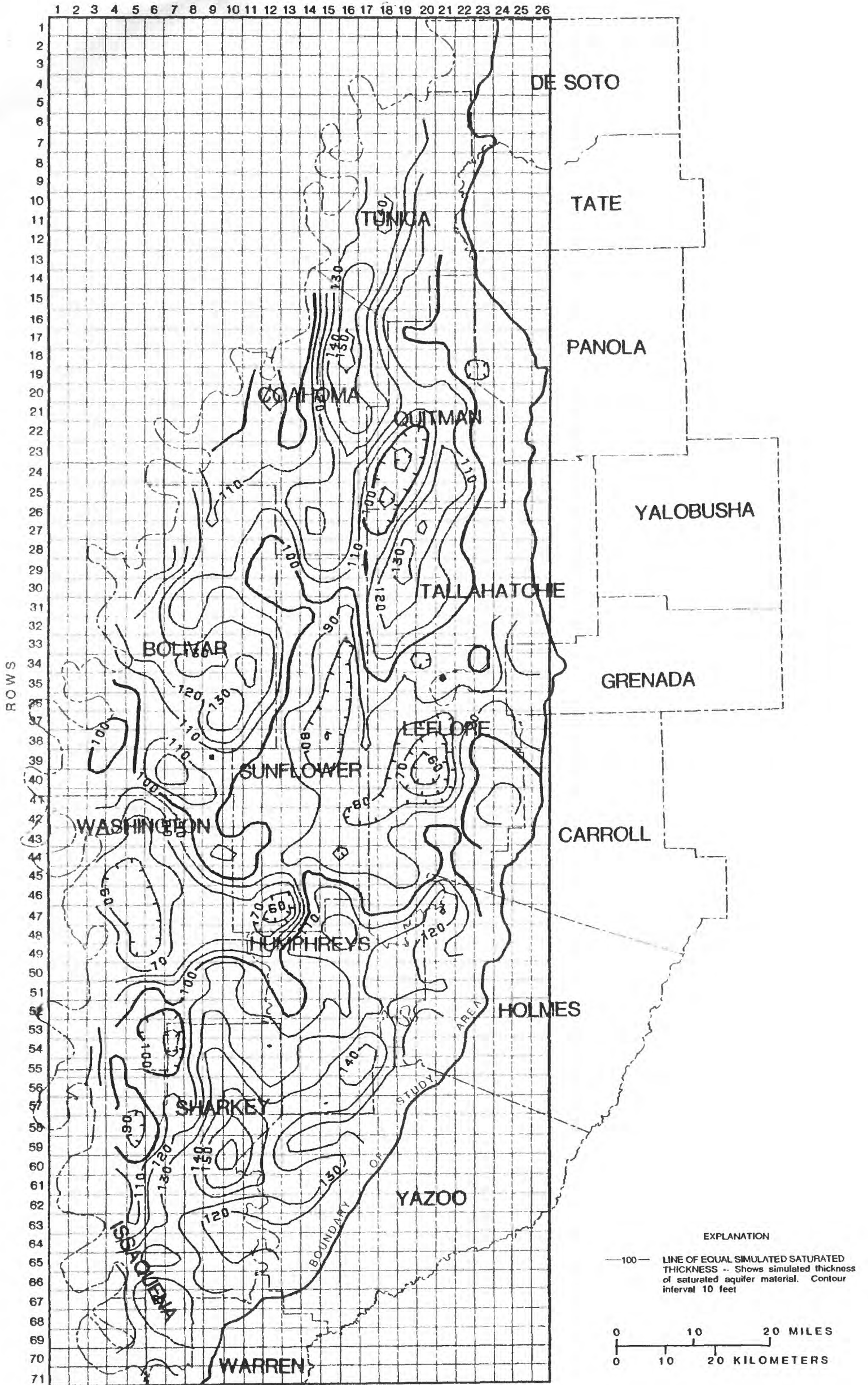

Figure 11.--Simulated saturated thickness of the Mississippi River alluvial aquifer for scenario 3 at year 2030. 